ACTA THERIOLOGICA

Vol. 31, 29: $401-408,1986$

\title{
Vole Snow Trails and Tunnels as Density Indicators
}

\author{
Lennart HANSSON
}

\begin{abstract}
Hansson L., 1986: Vole snow trails and tunnels as density indicators. Acta theriol., 31, 29: 401-408 [With 1 Table \& 2 Figs.]

The formation of trails on the snow surface and the digging of tunnels up to the snow surface by field voles Microtus agrestis was studied in order to establish their usefulness as indicators of density. The number of tunnels showed a negative correlation to the time since the start of winter, i.e., it was related to winter survival. However, this number was higher than the number of animals when snow thickness was below $30 \mathrm{~cm}$ and lower when it was above $30 \mathrm{~cm}$. The animals chose the energetically cheapest ways of constructing tunnels, many tunnels being located at human foot prints in the snow. The number of tunnels remained fairly constant for up to four days after snow-fall. Appropriate conditions for using tunnels as density indicators were thus restricted, and were even more limited as regards trails on the snow.
\end{abstract}

[Department of Wildlife Ecology, Swedish University of Agricultural Sciences, S-750 07 Uppsala, Sweden]

\section{INTRODUCTION}

Small rodents are usually censused by trapping. This is difficult during winter in snow-rich areas of the world although certain laborious methods are available (e.g. Larsson \& Hansson 1977, Schmid 1984). However, in some areas, such as northern Fennoscandia, there is a permanent snow cover for $7-8$ months and simpler methods would be a great advantage. Such methods may be based on tracks left by small mammals on or in the snow. Indices of this type have, provisionally, been used by Myllymäki (1970) and Hansson (1979) for this purpose.

These tracks are of two types, viz. foot prints (or trails) made while moving on the snow surface and holes ("air vents") dug to the snow surface from below and often marked with droppings just outside the exit. The latter may be a point of departure for sallies out on the snow surface but are usually not. In the present attempt to find simpler censusing methods it was conjectured, or hoped, that each small mammal might make one such tunnel and that a simple count of snow holes (tunnel openings) would enable estimations to be made of density. Al- 
ternatively, there might be a simple correlation between trail or hole densities and population density.

It was realized, however, that various snow conditions could affect the distribution and densities of these snow tracks. Therefore, relationships between snow tracks and population densities were examined during two winters, the first (1983-84) for establishing important factors and the second (1984-85) for more definite analyses.

\section{METHODS}

The studies were performed on abandoned fields c. $300 \mathrm{~m}$ from an official weather station close to Uppsala, south-central Sweden. The Uppsala area has fairly limited, yet variable, snow cover. Autumn trappings with Small Quadrats (Myllymäki et al., 1971) showed that Microtus agrestis (Linnaeus, 1761) was the only vole species on these fields but there were also some Apodemus and Sorex spp. as other small mammals. The trails of the latter could be distinguished and they were not counted but it is not known to what extent the latter species make snow tunnels up to the surface. Certain fixed lines on these fields were walked by boots or snow-shoes and trails crossing the route and snow-holes within $1 \mathrm{~m}$ on each side were counted. The censuses were made on the day after a snow-fall and again on a number of subsequent days, until the snow surface was destroyed by new snow, a thaw or by hard winds. A $25 \times 25 \mathrm{~m}$ enclosure in the same habitat was censused completely for trails and holes.

In $1983-84$ a fixed $425 \mathrm{~m}$ route was examined after twenty snow-falls, the same foot-step impressions being used on all occasions. Twenty field voles were released into the earlier empty enclosure in October but none survived until snow-melt in spring. The number of snow trails and holes were regressed against snow depth and time since December 1 in linear multiple regression models. Snow depth was soon found to affect the movements of the animals and the number of surviving animals inight approximately be related to the time since the start of winter, arbitrarily set at December 1.

The preliminary findings revealed that trails on the snow surface were fairly common in early winter, before the snow reached a depth of c. $10 \mathrm{~cm}$, and also in late winter when the snow cover was considerably deeper. Hardly any snow holes were made until the snow had reached a depth of $10 \mathrm{~cm}$ and before that the animals obviously used gaps in the only partly covered vegetation. They also appeared to prefer making tunnels up to my foot prints in the snow, which would be energetically more economical. Regressions with the more numerous 
holes were calculated both for all snow depths and depths $>10 \mathrm{~cm}$, thus producting two intercepts for holes but only one for trails in Table 1.

During the second winter the same route was censused as in the ccrlier winter and also a series of parallel routes, $525 \mathrm{~m}$ in length, in order to avoid the possible accumulation of tunnels ending in my foot

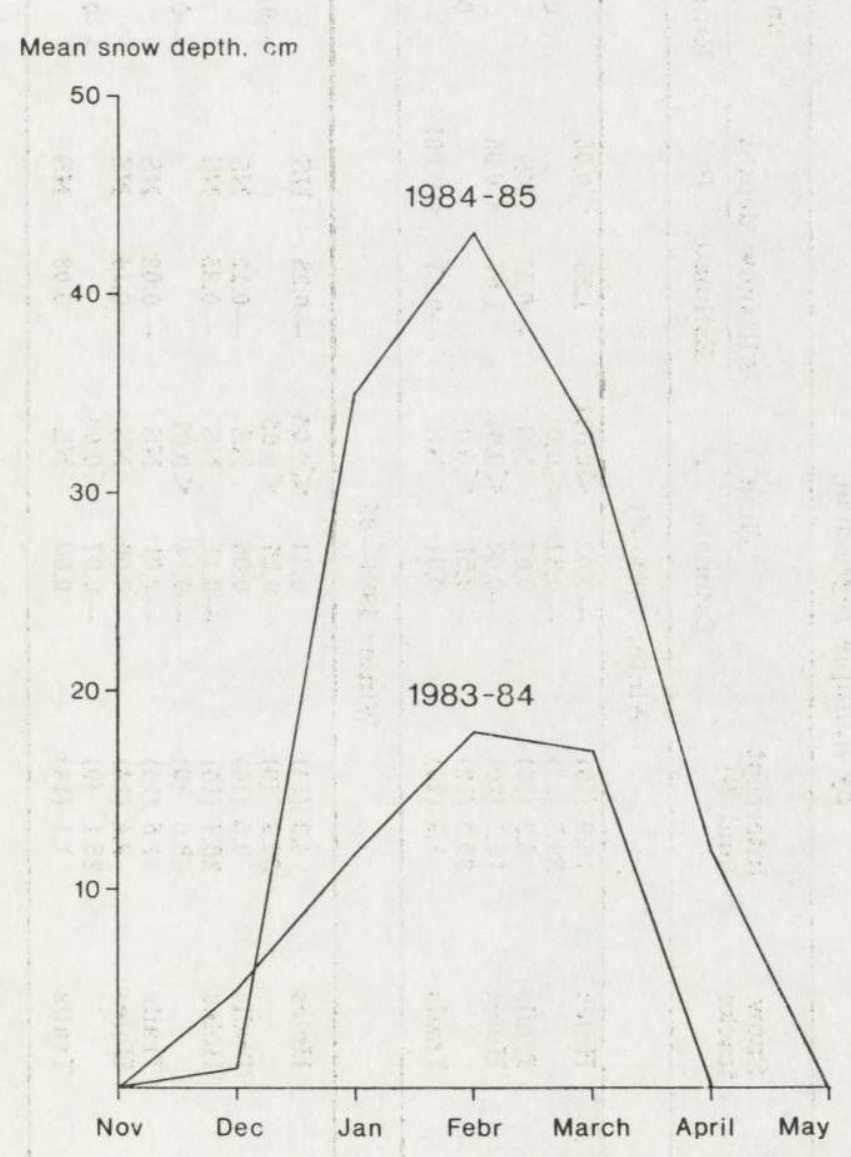

Fig. 1. Snow depths at Uppsala during the winters of $1983-84$ and $1984-85$.

prints. Twentyfive field voles were released inside the enclosure just before December 1 and were monitored during the winter by regular trapping. Seven animals survived until late April. This implied not only that the same analyses could be made as in the previous winter but also that the time since December 1 could be replaced with the real number of animals in the enclosure at the multiple regressions. Only 


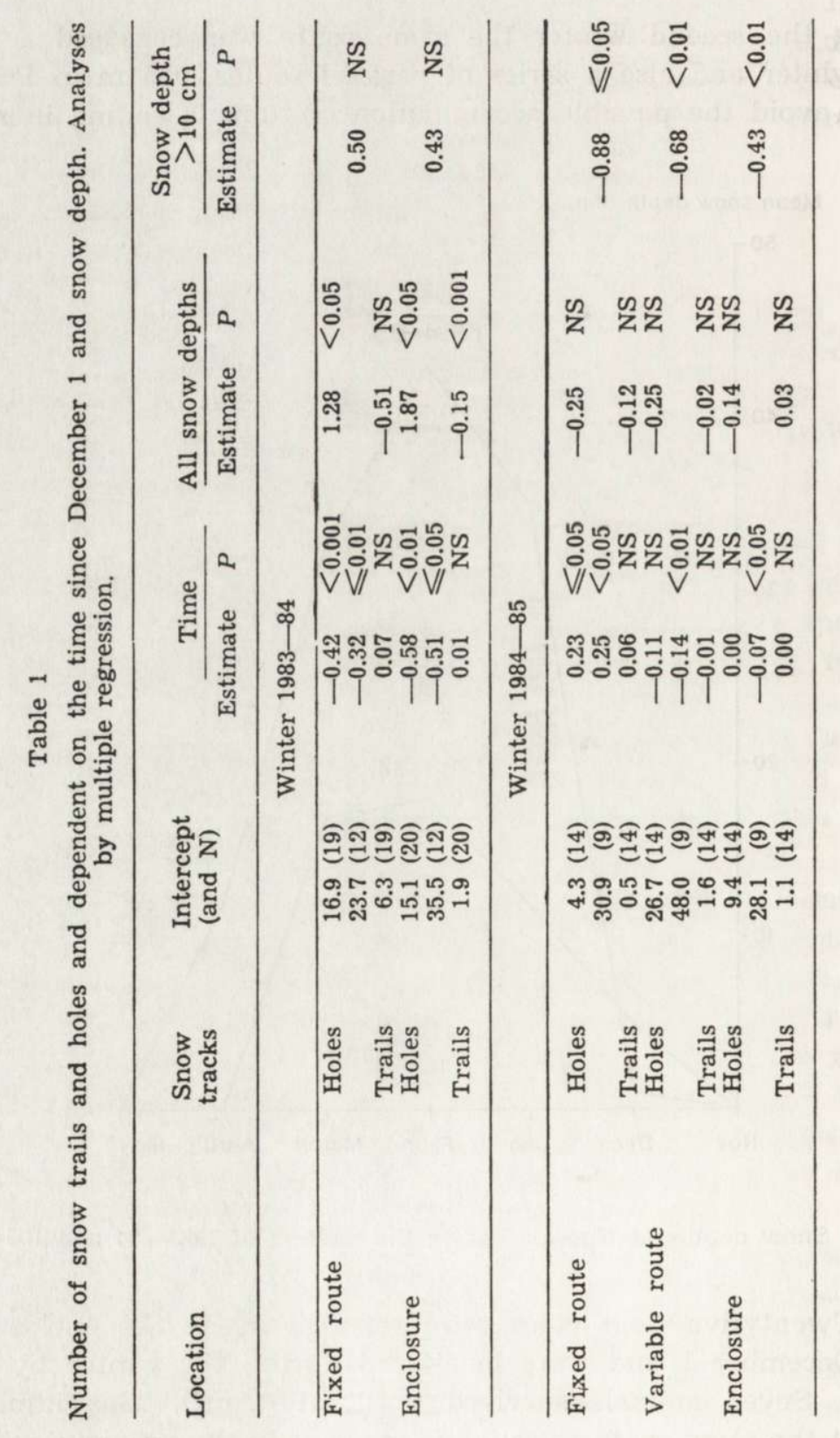


twelve surveys could be made after snow-falls in the 1984-85 winter. The maximum number of snow holes was 41 per route and 62 in the enclosure for both winters.

\section{RESULTS}

Snow conditions differed considerably between the years (Fig. 1), with much more snow during $1984-85$ than $1983-84$. Thus, the results obtained may be representative for a fajrly wide amplitude of snow depths. Small Quadrat indices of field vole densities did not differ significantly between the autumns of 1983 and 1984 .

During the first winter, poor in snow (Table 1), the number of snow holes showed consistently significant negative relations to the time since December 1 and positive relations with snow depth. The latter were significant only when all snow depths were considered. The number of trails on the snow showed negative correlations with snow depth, which were highly significant in the enclosure. There were too few trails on the snow surface for an analysis only when the snow cover was deeper than $10 \mathrm{~cm}$.

During the snow-rich winter 1984-85 the relations between snow holes and time since December 1 were negative on the variable routes and in the enclosure but positive for the fixed route. This was no doubt due to the increasing number of snow holes in the foot prints. especially in late winter when a lot of snow had fallen. In this winter the relation to snow depth had become negative and significantly negative when only snow covers deeper than $10 \mathrm{~cm}$ were considered. The number of trails showed no clear correlations with either time or snow depth but mainly negative relations to the latter.

The number of snow holes in the enclosure in 1984-85 was first regressed against only population densities of the field voles. This gave a significant correlation $(p<0.001)$ which explained $44 \%\left(r^{2}\right)$ of the variation. Inclusion of all snow depths into this model increased the explained variation only to $53 \%$. However, if only snow depths larger than $10 \mathrm{~cm}$ were included, in addition to vole density, the degree of explanation increased to $81 \%$. The latter equation was:

$$
\begin{array}{lll}
\begin{array}{l}
\text { (Density of } \\
\text { snow holes/ha) }
\end{array}=214+1.1 & \begin{array}{l}
\text { ivole density } \\
\text { in anim./ha) }
\end{array} & \begin{array}{l}
\text { (snow depth } \\
\text { in } \mathrm{cm} \text { ) }
\end{array}
\end{array}
$$

This implies that there were more snow holes than voles when the snow depth was less than c. $30 \mathrm{~cm}$ but fewer at greater snow depths.

The number of snow holes did not change particularly during the four first days after a snow-fall (Fig. 2). It was most stable on the fixed route, possibly due to the distribution at the foot prints. This number 
may even decrease somewhat, since certain old holes became covered with ice flakes in very cold weather.

\section{DISCUSSION}

Little is known why the voles make holes up to the snow surface but it is generally believed that they are for ventilating away $\mathrm{CO}_{2}$ accumulated by decomposition of decaying plant material in the subnivean space, which has a relatively high temperature (cf. e.g. Bashenina, 1956). Recent studies have also shown shifts in habitats by small rodents caused by high $\mathrm{CO}_{2}$ concentrations in certain places, especially in late winter (Penny \& Pruitt, 1984).

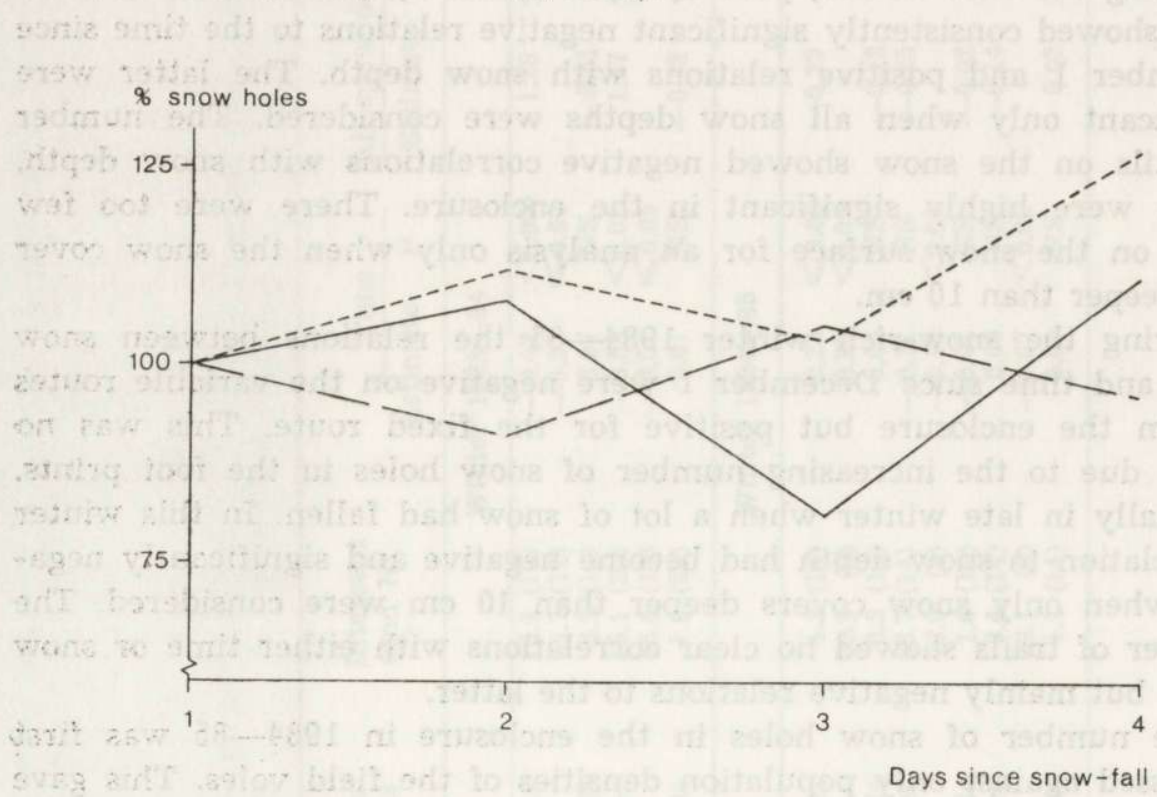

Fig. 2. Mean relative numbers of snow holes during one to three days after the first count $(=100 \%)$, which was made during the first day after a snow-fall.

$$
\begin{aligned}
& =\text { in the enclosure } \\
& =\text { along the fixed route }
\end{aligned}
$$

The movements of voles on the snow surface in early winter, with snow thickness less than $10 \mathrm{~cm}$, is probably just a continuation of their normal movements before the snow-fall. Extensive wanderings upcn the snow in late winter are more difficult to understand but are possibly related to $\mathrm{CO}_{2}$ accumulation or to incipient food deficits.

The construction of snow tunnels is obviously energetically expensive: 
The animals do not make any tunnels as long as the vegetation breaks the snow surface (less than $10 \mathrm{~cm}$ of snow), they dig towards depressed snow surfaces such as made by human foot prints and they reduce the number of tunnels when there is very thick snow cover. The latter observation may also indicate a change in social behaviour, with two or several animals sharing tunnels when snow depth exceeds c. $30 \mathrm{~cm}$. However, the importance of making these tunnels obviously overrides any energetic or social inconvenience.

The variations in snow tunneling imposed by the amount of snow obviously make it difficult to use snow holes as a good measure of vole density. Comparisons can thus only be made when srow conditions are similar in two areas or at two different times. The best opportunities seem to be at hand when the snow cover is c. $30 \mathrm{~cm}$ deep as the number of tunnels then should approximate the number of animals. Furthermore, repeated censuses in the same area should not be performed along exactly the same route since concentrations of snow holes in the foot prints may cause overestimates during later censuses. On the other hand, if snow cover is generally increasing while foot prints remain at a previous snow level comparisons in time may be facilitated with a fixed route. Neither does it seem very important to make a census directly after a snow-fall as a fairly constant number of tunnels is retained for a rather long period.

The usefulness of trails is even more limited for this species, especially in late winter, as the factors leading to a supranivean activity are almost unknown. However, trails may be more useful for other species as the bank vole, Clethrionomys glareolus (Schreber, 1780), which seems to move more about on the snow surface.

Acknowledgements. In am grateful to Heikki Henttonen for comments. The field work was supported by the Swedish Council for Forestry and Agricultural Research.

\section{REFERENCES}

1. Bashenina N. V., 1956: Influence of the quality of the subnivean air on the arrangement of winter nests of voles. Zool. Zhurn., 35: 940-942. [In Russian with English summary].

2. Hansson L., 1979: Field signs as indicators of vole abundance. J. Appl. Ecol., 16: $339-347$.

3. Larsson T.-B. \& Hansson L., 1977: Sampling and dynamics of small rodents under snow cover in northern Sweden. Z. Säugetierk., 42: 290-294.

4. Myllymäki A., 1970: Population ecology and its application to the control of the field vole, Microtus agrestis (L.). EPPO Publ. Ser. A., 58: 27-48.

5. Myllymäki A., Paasikallio A., Pankakoski E. \& Kanervo V., 1971: Removal experiments on small quadrats as a mean of rapid assessment of the abundance of small mammals. Ann. Zcol. Fennici, 8: 177-185. 
6. Penny C. E. \& Pruitt P. O., 1984: Subnivean accumulation of $\mathrm{CO}_{2}$ and its effects on winter distribution of small mammals. Spec. Publ. Carn. Mus. Nat. Hist., 10: $373-380$.

7. Schmid W. D., 1984: Materials and methods of subnivean sampling. Spec. Publ. Carn. Mus. Nat. Hist., 10: 25-32.

Accepted, March 25, 1986.

\section{Lennart HANSSON}

SLADY NA SNIEGU I TUNELE NORNIKOW JAKO WSKAẐNIKI ZAGĘSZCZENIA

\section{Streszczenie}

Układ śladów norników Miçrotus agrestis na powierzchni śniegu i tworzenie tuneli pod śniegiem były badane w celu ustalenia ich przydatności jako wskaźników zagęszczenia. Liczba tuneli była ujemnie skorelowana z czasem, licząc od początku zimy, czyli związana była z przeżywalnością. Liczba tuneli była wyższa, niż liczba osobników gdy pokrywa śnieżna nie przekarczała $30 \mathrm{~cm}$, a niższa, kiedy warstwa sięgała powyżej $30 \mathrm{~cm}$. Zwierzęta budowały tunele w sposób energetycznie najoszczędniejszy, często lokując je na śladach ludzi na śniegu. Liczba tuneli pozostawała nie zmieniona do czwartego dnia po opadzie śniegu. Wobec tego warunki korzystne do użycia liczby tuneli jako wskaźnika były ograniczone nawet bardziej, niż w przypadku śladów. 